\title{
Could Allelic Discrimination in ETS2 Predispose Individuals to Breast Cancer?
}

\author{
Arpita Chatterjee ${ }^{1}$, Nupur Mukherjee ${ }^{2}$, Chinmay Kumar Panda ${ }^{2}$ and Kanchan Mukhopadhyay ${ }^{*}, 1$ \\ ${ }^{I}$ Manovikas Biomedical Research and Diagnostic Centre, MRIH, Kolkata, India \\ ${ }^{2}$ Chittaranjan National Cancer Institute, Kolkata, India
}

\begin{abstract}
The V-ets erythroblastosis virus E26 oncogene homolog2 (ETS2) is known to have a stimulatory role in breast cancer progression. To find out its participation in the development of breast cancer, we have investigated a functional polymorphism in ETS2, rs461155, in a group of breast cancer patients. Allelic and genotypic frequencies obtained were compared with that obtained for ethnically matched healthy control individuals and data reported for four other ethnic groups in the HapMap project. Significant differences in genotypic frequencies were obtained between breast cancer patients and control individuals $(\mathrm{p}<0.0001)$. Ethnic groups reported to have higher frequency of breast cancer were observed to have higher frequency of the " $\mathrm{G}$ " allele $(\mathrm{p}<0.01)$. In silico analysis revealed that this allele interferes in proper splicing of the ETS2 transcript and thus can alter function of the protein which in turn can influence breast cancer development.
\end{abstract}

The $V$-ets erythroblastosis virus E26 oncogene homolog2 (ETS2) is a well known transcription factor (TF) that regulates expression of a number of cell cycle regulator genes like Bcl-xL, c-myc, cyclin D1 and P53 [1,2]. Over expression of ETS2 causes upregulation of $P 53, B A X$ and down regulation of $B c l 2$, thus increasing sensitivity to apoptosis [3]; therefore, ETS2 can act as a tumor suppressor. On the other hand, in breast cancer (BC), investigators have reported that ETS2 negatively regulates the $B R C A 1$ promoter [4].

$\mathrm{BC}$ is of major concern in the world with a very high occurrence among residents of U.S having ancestry from northern and western Europe (CEU) and Yoruba populations from Nigeria (YRI) [5]. Considering the contribution of ETS2 in the field of cell cycle regulation, apoptosis etc. the present study was aimed at investigating role of ETS2 functional polymorphisms in association with BC.

Chromosomal localization of ETS2 is at 21q22.3 [6]. ETS family members have a conserved DNA-binding domain (ETS domain) composed of a helix-turn-helix sequence and recognize a $(\mathrm{C} / \mathrm{A})(\mathrm{C} / \mathrm{A}) \mathrm{GGA}(\mathrm{A} / \mathrm{T})(\mathrm{A} / \mathrm{G})$ motif and binds to GGAA/T core motif [7, 8]. Among different functional polymorphisms in ETS2, one intronic (rs35258008) and three exonic SNPs (rs457705, rs461155, rs34120017), located at the DNA binding domain, were investigated in the present study (details provided in Table 1).

Post-operative normal tissue adjacent to malignant breast tumor was collected from BC patients $(\mathrm{n}=49)$ and genomic DNA was extracted from tissue [9]. Genomic DNA from ethnically matched healthy control individuals $(n=144)$ was collected from peripheral blood [9]. Target sequence

*Address correspondence to this author at the Manovikas Biomedical Research and Diagnostic Centre, MRIH, Kolkata, India;

E-mail:kanchanmvk@yahoo.com encompassing all the studied SNPs was amplified by polymerase chain reaction using primer sets; forward "5GTTGTCTTTGCCAGGGACTC-3" and reverse "5CGGTGAATGTGGTACTGTGG-3". The amplification condition was 5 minutes initial denaturation at $95^{\circ} \mathrm{C}$ followed by 35 cycles of denaturation at $95^{\circ} \mathrm{C}$ for 45 seconds, annealing at $58^{\circ} \mathrm{C}$ for 40 seconds, extension at $72^{\circ} \mathrm{C}$ for 45 seconds and a final extension of 5 minutes at $72^{\circ} \mathrm{C}$. Amplicons (365 bp) were subjected to sequencing in ABI prism 3130 Genetic Analyzer using Big Dye sequencing kit v3.1 followed by analysis using Sequencing Analysis software v 5.2.

Data obtained were analyzed statistically to compare allelic and genotypic distribution in the control and $\mathrm{BC}$ groups. rs 457705 , rs34120017, rs35258008 were found to be non-polymorphic in the studied eastern Indian population. rs461155 was polymorphic and allelic/genotypic frequencies obtained were compared with the data available from the HapMap project on four major populations in the world, namely CEU, YRI, Han Chinese from Beijing, China (HCB) and Japanese from Tokyo, Japan (JPT). Functional analysis for the TF was performed using web-based tools. Incidence of $\mathrm{BC}$ in different populations was obtained from published data (c.ref 5; GLOBOCAN 2002; Cancer research UK.org/statistics).

Genotypic data obtained in the present study indicated that while rs457705, rs34120017, rs35258008 were nonpolymorphic in the eastern Indian population, the " $\mathrm{T}$ " allele of rs 457705 had $100 \%$ prevalence. On the contrary, the "T" allele was found to be the minor allele in CEU and YRI population and in HCB and JPT populations it had only 61$63 \%$ prevalence [10]. Allelic and genotypic distribution of rs461155 in control and BC groups revealed statistically significant higher occurrence of the " $G$ " allele in the later group (Table 2). 
Table 1. Different Sites in ETS2 Investigated in the Present Study

\begin{tabular}{|c|c|c|c|c|}
\hline SNP ID & Type & Alleles & Amino Acid Position & Effect \\
\hline \hline rs457705 & Synonymous SNP & G/T & 272 & Splicing regulation by SC35 (Pupasuite analysis) \\
\hline rs461155 & Synonymous SNP & A/G & 341 & Splicing regulation by SRp40 (Pupasuite analysis) \\
\hline rs34120017 & Deletion/Insertion polymorphism & $-/ C$ & 345 & Frame shift \\
\hline rs35258008 & Deletion/Insertion polymorphism & -/A & - (Intronic) & - \\
\hline
\end{tabular}

Table 2. Allelic and Genotypic Frequencies of rs461155 in Control and Breast Cancer Subjects

\begin{tabular}{|c|c|c|c|c|c|c|c|c|}
\hline \multirow{2}{*}{ Groups } & \multirow{2}{*}{$\mathbf{N}$} & \multicolumn{2}{|c|}{ Allele } & \multirow[t]{2}{*}{$\chi^{2}, \mathbf{p}$ Value } & \multicolumn{3}{|c|}{ Genotype } & $\chi^{2}, \mathbf{p}$ Value \\
\hline & & $\mathbf{A}$ & $\mathbf{G}$ & & $\mathbf{A A}$ & AG & GG & \multirow{3}{*}{$31.1,<0.0001$} \\
\hline Control & 144 & 0.618 & 0.382 & \multirow{2}{*}{$4.21,0.040$} & 0.361 & 0.514 & 0.125 & \\
\hline $\mathrm{BC}$ & 49 & 0.50 & 0.50 & & 0.020 & 0.960 & 0.020 & \\
\hline
\end{tabular}

Comparative analysis of allelic frequencies for rs461155 among the CEU, HCB, JPT, YRI and eastern Indian populations revealed statistically significant higher frequency of the " $G$ " allele in CEU $(p<0.0001)$ and YRI $(\mathrm{p}<0.05)$ populations (Table 3$)$. Further, comparison between these populations for the occurrence of BC (Fig. 1) showed that CEU and YRI have significantly higher incidence $(\mathrm{p}<0.0001)$.

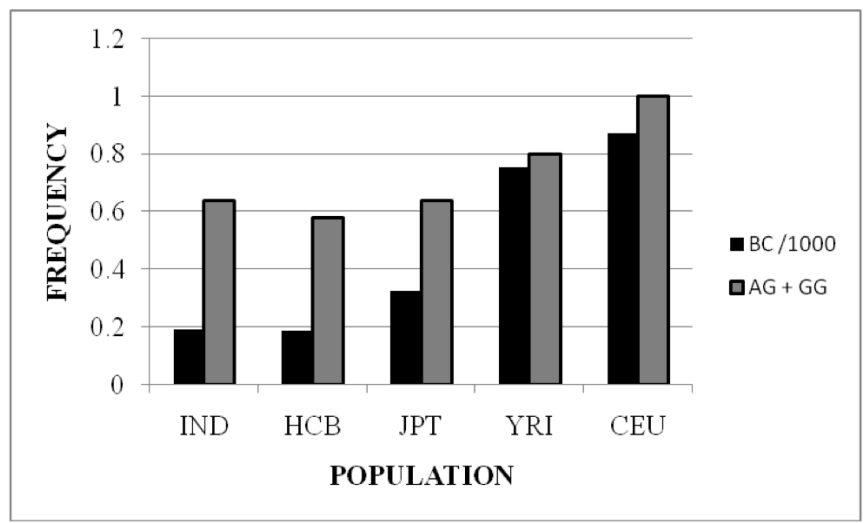

Fig. (1). Comparative analysis of genotypes (AG+GG) and age-standardized incidence of breast cancer (2002 estimates) in different populations.

Pupasuite analysis showed that the score for SRp40 activity, as exonic splicing enhancer, is 4.00 for the " $A$ " allele and 1.39 for the " $G$ " allele [11]. Therefore, higher occurrence of the rs461155 "G" allele may lead to loss of SRp40 mediated splicing of pre-mRNA and alter/reduce ETS2 activity. FastSNP analysis [12] also revealed that rs461155 could be considered as a "medium risk" SNP (risk level: 2-3).

Since rs461155 "G" allele may alter splicing of this important $\mathrm{TF}$, it can be speculated that target genes further downstream of ETS2 could be regulated incorrectly; along with the P53 mediated apoptotic pathway and cell cycle regulatory pathways, ErbB2-mediated regulation of BC may also be altered since down regulation of ETS2 leads to overexpression of $E r b B 2$ [13, 14]. Therefore, in addition to its action on $B R C A 1$ [4], ETS2 may influence development of BC through P53 and ErbB2 mediated pathways.

The "G" allele was found to be present in higher frequencies in both heterozygous as well as homozygous conditions in the CEU and YRI populations in comparison to the Asian population groups. Further investigations are necessary to find out whether this could be related to the reported higher occurrence of $\mathrm{BC}$ in these two populations.

The present study is the first to report frequency of rs461155 in the Indian population. From the result obtained it is evident that there is a clear over-representation of the ' $\mathrm{G}$ ' allele in BC patients in contrast to the controls. It may be hypothesized from the current investigation that, along with other internal and external causative factors of $\mathrm{BC}$, presence of ETS2 rs461155 ' $\mathrm{G}$ ' allele may hinder splicing of ETS2 by

Table 3. Comparison of Allelic and Genotypic Frequencies for rs461155 in Different Populations

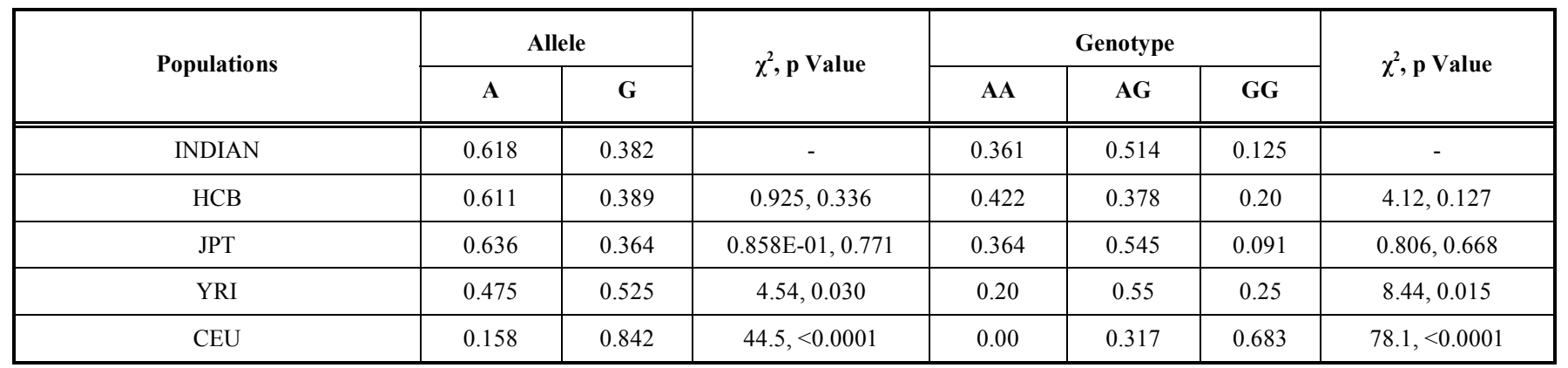


SRp40, thereby resulting in down regulation of ETS2. Further research investigating the role of ETS2 as a candidate for $\mathrm{BC}$ is warranted in the light of the present investigation.

\section{REFERENCES}

[1] Carbone GM, Napoli S, Valentini A, Cavalli F, Watson DK, Catapano CV. Triplex DNA-mediated downregulation of Ets2 expression results in growth inhibition and apoptosis in human prostate cancer cells. Nucl Acids Res 2004; 32: 4358-67.

[2] Sementchenko VI, Watson DK. Ets target genes: past, present and future. Oncogene 2000; 19: 6533-48.

[3] Wolvetang EJ, Wilson TJ, Sanij E, et al. ETS2 overexpression in transgenic models and in Down syndrome predisposes to apoptosis via the 553 pathway. Human Mol Genet 2003; 12: 247-55.

[4] Baker KM, Wei G, Schaffner AE, Ostrowski MC. Ets-2 and components of mammalian SWI/SNF form a repressor complex that negatively regulates the BRCA1 promoter. J Biol Chem 2003; 278: 17876-84.

[5] Parker SL, Davis KJ, Wingo PA, Ries LA, Heath CW Jr. Cancer Statistics by Race and Ethnicity. CA Cancer J Clin 1998; 48: 3148.
[6]

Sacchi N, Watson DK, Guerts van Kessel AH, et al. Hu-ets-1 and $\mathrm{Hu}$-ets-2 genes are transposed in acute leukemias with $(4 ; 11)$ and $(8 ; 21)$ translocations. Science 1986; 231: 379-82.

[7] Karim FD, Urness LD, Thummel CS, et al. The ETS-domain: a new DNA-binding motif that recognizes a purine-rich core DNA sequence. Genes Dev 1990; 4: 1451-53.

[8] Sharrocks AD, Brown AL, Ling Y, Yates PR. The Ets-domain transcription factor family. Int J Biochem Cell Biol 1997; 29: 137187.

[9] Miller SA, Dykes DD, Polesky HF. A simple salting out procedure for extracting DNA from human nucleated cells. Nucl Acids Res 1988; 16: 1215.

[10] Human genome SNP database. Available at: http://www.ncbi.nlm. nih.gov/SNP/

[11] Conde L, Vaquerizas JM, Santoyo J, et al. PupaSNP Finder: a web tool for finding SNPs with putative effect at transcriptional level. Nucl Acids Res 2004; 32: W242-8.

[12] Yuan HY, Chiou JJ, Tseng WH, et al. FASTSNP: an always uptodate and extendable service for SNP function analysis and prioritization. Nucl Acids Res 2006; 34:W635-41.

[13] Haverty PM, Fridlyand J, Li L, et al. High-resolution genomic and expression analyses of copy number alterations in breast tumors. Genes Chromosomes Cancer 2008; 47: 530-42.

[14] Scott GK, Chang CH, Erny KM, et al. Ets regulation of the erbB2 promoter. Oncogene 2000; 19: 6490-502.

Received: June 8, 2009

Revised: September 1, 2009

Accepted: September 3, 2009

(C) Chatterjee et al.; Licensee Bentham Open.

This is an open access article licensed under the terms of the Creative Commons Attribution Non-Commercial License (http://creativecommons.org/licenses/by-nc/

3.0/) which permits unrestricted, non-commercial use, distribution and reproduction in any medium, provided the work is properly cited. 